\title{
Cutaneous Fibrous Histiocytoma
}

National Cancer Institute

\section{Source}

National Cancer Institute. Cutaneous Fibrous Histiocytoma. NCI Thesaurus. Code C6801.

A solitary, slowly growing, nodular mass, most often affecting the extremities. It is composed of fibrous and histiocytic cells which infiltrate the dermis and occasionally the underlying subcutaneous tissue. Usually local excision is curative. Recurrences are reported only in a small minority of cases. 